\begin{tabular}{|l|l|l|l|l|l|}
\hline J. Tek. Ling & Vol.11 & No.3 & Hal. 341 - 351 & Jakarta, September 2010 & ISSN 1441-318X \\
\hline
\end{tabular}

\title{
TEKNIK BUDIDAYA IN VITRO Eleutherine sp. (Bawang Sabrang)
}

\author{
Djadja Siti Hazar Hoesen
}

\author{
Peneliti di Bidang Botani Puslit Biologi, LIPI \\ Cibinong Science Center (CSC), Jl. Raya Jakarta-Bogor Km46 Cibinong \\ E-mail hoesensitihazar@yahoo.com
}

\begin{abstract}
Vegetative propagation from bulb excised of Eleutherine sp. (Iridaceae) were cultured in Murashige and Skoog (MS) medium supplemented with plant growth regulator (PGR) Benzyl adenine (BA) $1 \mathrm{mg} / \mathrm{l}$ at initiation stage, BA (2 and 5) $\mathrm{mg} / \mathrm{l}$ for induced shoot buds formation at multiplication stage. In this study also BA $2 \mathrm{mg} / \mathrm{l}$ and BA $2 \mathrm{mg} / \mathrm{l}$ combined with naphthalein acetic acid (NAA) $0.5 \mathrm{mg} / \mathrm{l}$ were treated for rooting planlets formation. Calli formation were induced with auxin PGR picloram $1 \mathrm{mg} / \mathrm{l}$ combined with 2,4 dichlorophenoxy acetic acid (2,4-D) 0.5 and $1 \mathrm{mg} / \mathrm{l}$ in concentrations. The media contained $2 \mathrm{mg} / \mathrm{l}$ cytokinin (BA) without auxin (NAA), resulted the highest shoot buds formation. Rooting planlets were produced in MS medium combined with BA and NAA. MS medium contains Picloram $1 \mathrm{mg} / \mathrm{l}$ and 2,4-D $1 \mathrm{mg} / \mathrm{l}$ was optimal for frequency on calli initiation (100\%) and the largest diameter of calli also represented in cultured MS medium with picloram $1 \mathrm{mg} / \mathrm{l}$ and 2,4-D $1 \mathrm{mg} / \mathrm{l}$. In acclimatization stage, $100 \%$ of planlets survived and successfully transplanted to soil medium in the field.
\end{abstract}

Key words: in vitro, Eleutherine sp.

\section{PENDAHULUAN}

\subsection{Latar Belakang}

Bawang sabrang, babawangan beureum, bawang siyem, bawang dayak atau bawang kapal (Eleutherine sp.), tumbuhan tersebut termasuk keluarga Iridaceae (Ordo Liliales) berasal dari daerah tropis Amerika, di Indonesia diduga awal penyebarannya dari pulau Kalimantan, penamaan 'sabrang' berhubungan pula dengan lokasi asal tumbuhan tersebut, karena orang dari luar pulau Kalimantan (Jawa) kalau akan mengambil harus "nyabrang" atau menyeberang (Heyne, 1987)1). Di pulau Jawa tumbuhan tersebut ditanam penduduk sebagai tanaman hias, atau banyak dijumpai di perkebunan teh, kina dan karet (Backer and Bakhuizen, 1968)2). Eleutherine sp.
Merupakan tumbuhan herba yang tumbuh alami di ketinggian tempat 600-1500 dpl. Bawang sabrang ini mengandung senyawa alkaloid, saponin, tri terpenoid, steroid, glikosida, tanin, fenolik dan flavonoid. yang dapat dimanfaatkan sebagai bahan baku obat (Anonim, 2009b www.bazar.co.id) ${ }^{3}$. Tumbuhan tersebut banyak dimanfaatkan baik sebagai obat peluruh kemih, obat muntah, pencahar, obat penyakit kuning dan kelamin. Tumbuhan babawangan ini, juga dapat mengatasi beberapa keluhan seperti kanker payudara (Bintari, 2002) ${ }^{4}$, kista, prostat, diabetes, asam urat, hipertensi, gangguan pencernaan lambung, kolesterol, gondok, bronkhitis, kurang stamina dan gangguan seksual. Umbi mentah di daerah asal bahan tumbuhan tersebut diambil (desa 
Teun, Kec. Raimanuk, Kab. Belu, NTT) biasa digunakan untuk obat apabila buang air besar berdarah/radang usus atau penduduk memanfaatkannya juga sebagai tanaman hias di pekarangan (komunikasi pribadi). Umbi yang telah dipanggang, perasannya dapat dimanfaatkan untuk mengobati penyakit kuning dan kelamin, bagian daun juga bisa bermanfaat untuk wanita yang sedang nifas (Heyne, 19871); Winarto, 2007)5). Di Filipina, umbi dari tumbuhan tersebut dipercaya dapat mengurangi rasa sakit (anti analgesik) (Perry and Metzger, 1980)6) bahkan orang Indian Barat mempercayai tumbuhan tersebut mempunyai kekuatan gaib (Burkill, 1966). Untuk menanggulangi penyakit layu pada pisang, dapat dilakukan pola pergiliran tanaman dengan bawang sabrang pada lahan untuk pertanaman pisang. Pergiliran tanaman dengan bawang sabrang dilaporkan dapat menurunkan serangan penyakit layu, diduga bawang sabrang memiliki zat alelopati yang dapat menghambat patogen (Anonim, 2007 http://insidewinme.blogspot.com $)^{7}$. Sebagai antiinflammasi dapat digunakan umbi Bawang sebrang (Eleutherine americana Merr), dicampur dengan rimpang Temulawak (Curcuma xanthorriza Roxb), dan akar Pepaya (Carica papaya L) (Sa'roni.dkk. 1987) ${ }^{8}$. Ekstrak segar dari umbinya menghasilkan efek antibakteri (Voravuthikunchai et al, 2009 http://www.nursingspirit.com). Umbi bawang sabrang/tiwai (Eleutherine americana (Aubl.) Merr.), secara tradisional digunakan untuk mengobati kanker oleh sebagian masyarakat Kalimantan (Firdaus dkk., 2007)9), E. bulbosa (Miller) Urban, jenis ini oleh sebagian masyarakat sebagai obat untuk mengeluarkan cacing/'vermifuge', datang bulan tidak teratur, ganggguan usus dan menghilangkan rasa sakit; bahkan dapat digunakan juga sebagai antifertilitas. Risom dari E. subaphylla Gagnep. Digunakan untuk menghentikan pendarahan/'haemostatic dan anti bakteri. Dari genus Eleutherine tersebut berhasil pula dianalisa kandungan senyawa kimianya al. elecanicin, eleutherol, isoeleutherol, eleutherin, isoeleutherin, hongconin efeknya sama dengan anthraquinone dan glycosides. Senyawa aktif yang terkandung dalam umbi genus Eleutherine tersebut mempunyai aktifitas biologis yang penting. Hara et al. $(1997)^{10)}$ menemukan, bahwa eleutherine merupakan tipe senyawa yang "noncleavable complex" seperti tipe topoisomerase II yang mempunyai daya hambat yang spesifik dan selektif, selain itu dilaporkan pula bahwa isoeleutherin dan isoeleutherol mempunyai daya hambat terhadap HIV pada pembelahan sel 'H9 lymphocytes'. Daya anti jamur dari senyawa dichloromethane juga ditemukan dari ekstrak umbi $E$. bulbosa, selain senyawa-senyawa tersebut, ditemukan juga xanthones mangiferin and isomangiferin dari ekstrak daunnya. Eleutherinon a fungitoxic naphtoquinone yang dihasilkan dari $E$. bulbosa (Alves et al, 2003) ${ }^{11)}$. Terdapat tiga senyawa 'anthraquinones' dari E. americana , salah satunya dapat menghambat proliferasi sel leukimia pada manusia (Jinzhong, et al. $2006)^{12)}$ senyawa lainnya yaitu 'naphthalene derivatives' juga dihasilkan dari jenis tersebut (Han, et al. 2006) ${ }^{13}$. Di samping sebagai bahan obat, tumbuhan Eleutherine sp. berpotensi juga sebagai tanaman hias, bunganya berwarna putih, putik berwarna kuning dan berdiameter sekitar $3 \mathrm{~cm}$, mekarnya pada sore hari (Foto 2).

Bawang sabrang biasanya diperbanyak melalui umbinya, penelitian budidaya konvensional Eleutherine bulbosa, dengan perlakuan 3 tingkatan berat umbi bibit dan 2 tingkat jarak tanam telah dilaporkan (Ming, 2009) ${ }^{14)}$. Hasil penelitian mengindikasikan bahwa ukuran umbi yang lebih besar dengan jarak tanam yang lebih lebar meningkatkan biomasa umbinya, sementara indeks pemanenan yang lebih tinggi berasal dari umbi/bibit yang lebih berat dengan jarak tanam yang sempit (Ming, 2009) ${ }^{14)}$. Sementara budidaya nonkonvensional/ in vitro, belum ditemukan laporannya. Diharapkan dari percobaan ini dapat dikuasai suatu teknik budidaya in vitro yang akan menjadi bahan acuan untuk diaplikasikan pada pembudidayaan massal, yang akan 


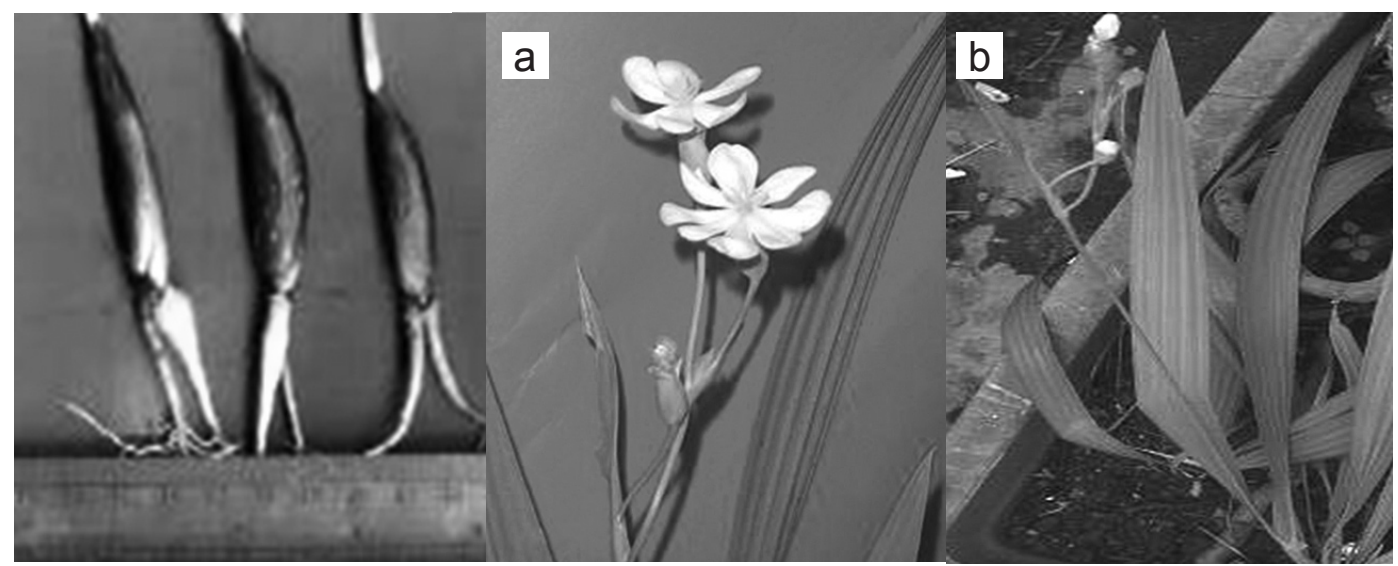

Gambar 1. Umbi sebagai bahan eksplan

menunjang penyediaan bahan baku industri obat atau untuk tanaman hias.

\subsection{Tujuan Penelitian}

Penelitian ini bertujuan untuk mengevaluasi perlakuan zat pengatur tumbuh sitokinin (BA) dan auksin (pikloram, NAA dan 2,4-D), terhadap pertumbuhan, perkembangan tunas/planlet dan pembentukan kalus embrionik eksplan kultur Eleutherine sp., dan untuk mendapatkan konsentrasi yang berpengaruh terhadap eksplan secara optimal.

\section{METODOLOGI PENELITIAN}

\subsection{Bahan}

Bahan eksplan berupa umbi (Gambar 1), berasal dari Desa Teun Kecamatan Raimanuk Kabupaten Belu. Nusa Tenggara Timur. Daerah tersebut berketinggian tempat sekitar $600 \mathrm{~m}$ dpl.

\subsection{Peralatan}

Alat yang digunakan pada proses penanaman secara in vitro antara lain adalah pinset, scalpel, mata pisau steril, laminar air flow cabinet untuk penanaman secara aseptis, autoclave, $\mathrm{pH}$ meter dan peralatan laboratorium lainnya. Aklimatisasi (penanaman secara ex
Gambar 2. Bunga mekar (a) dan kuncup (b)

vitro) rumah kaca, rak untuk menyimpan pot.

\subsection{Waktu dan Tempat Penelitian}

Penelitian ini dilakukan di laboratorium Treub (Lab. Fisiologi Tumbuhan dan Kultur Jaringan) Bidang Botani Puslit Biologi-LIPI dan laboratorium kultur sel dan jaringan Bid. Botani Puslit Biologi-LIPI di CSC pada tahun 2006-2008.

\subsection{Metode Penelitian}

Percobaan teknik in vitro pada eksplan umbi Eleutherine sp. melalui beberapa tahapan :

Tahap Inisiasi: Umbi dibersihkan dengan air yang mengalir hingga tidak ada lagi kotoran yang melekat, kemudian disterilkan dengan larutan klorox 30-40\% selama 20 menit, dibilas air suling steril 3-4 kali. Umbi yang telah disterilkan tersebut dikupas bagian lapisan yang telah menyerap larutan klorox hingga umbi berukuran diameter 0,3-0,5 cm sebagai eksplan, kemudian ditanam dalam media MS tanpa ZPT dan $\mathrm{MS}+1 \mathrm{mg} / \mathrm{l}$ BA. Perlakuan percobaan pada tahap inisiasi adalah untuk mendapatkan kultur yang steril dan untuk menginduksi inisiasi tunas. Pengamatan pada tahap tersebut adalah persen kultur hidup, steril dan saat muncul bakal tunas. 
Tahap perbanyakan: Tahap tersebut adalah untuk menginduksi pembentukan tunas/anakan. Setelah kultur berumur 6 minggu dari saat subkultur pertama pada media dasar yang ditambah $1 \mathrm{mg} / \mathrm{l} \mathrm{BA}, 2 \mathrm{mg} / \mathrm{l}$ BA, $5 \mathrm{mg} / \mathrm{BA}$ dan kontrol. Subkultur ke dua dilakukan setelah 6 minggu dari subkultur pertama pada media dasar yang ditambah BA dan NAA. Parameter yang diamati pada tahap perbanyakan adalah jumlah anakan, jumlah daun dan tinggi/panjang tunas/planlet. Subkultur ke dua dilakukan 6 minggu kemudian dari saat subkultur pertama, bertujuan untuk menginduksi akar dan kalus. Rancangan pada penelitian ini adalah rancangan acak lengkap, dengan 10 ulangan (masing-masing perlakuan 50 eksplan). Untuk menginduksi kalus yang embriogenik, kultur kalus tersebut dipindahkan ke dalam media yang ditambah (0 dan 1) mg/l pikloram dan (0; 0,5 dan 1) 2,4-D.

Tahap pembesaran planlet: Setelah tunas dipisahkan menjadi individu-individu, dilakukan pemindahan pada media dasar MS tanpa ZPT, pembentukan dan pertumbuhan tunas yang berakar diamati.

Aklimatisasi: Pada tahapan tersebut dilakukan pemeliharaan tanaman di luar botol (ex vitro), Planlet yang berakar dengan ukuran dan morfologi tanaman yang telah proporsional yaitu tinggi $>10 \mathrm{~cm}$, akar $>5$ dan daun $>3$, dikeluarkan dari botol, direndam dalam larutan fungisida dan dipindahkan pada media yang dipersiapkan untuk tahap aklimatisasi yaitu campuran tanah, pasir dan kompos dengan perbandingan $1: 1: 2$, media dan tanaman tersebut dimasukkan ke dalam pot dan dipelihara di rumah kaca.

\section{HASIL DAN PEMBAHASAN}

\subsection{Tahap Inisiasi}

Hari ke tiga hingga ke enam setelah inisiasi, tampak sejumlah kultur terkontaminasi mikroorganisma yaitu sekitar 3\%. Kultur yang lainnya telah menunjukkan adanya pertumbuhan dan munculnya bakal tunas. Setelah 6 minggu dari awal penanaman secara in vitro, planlet telah terbentuk. Nilai rataan tunas dan jumlah daun pada kultur dalam media yang ditambah sitokinin (1 $\mathrm{mg} / \mathrm{l}$ BA) menghasilkan nilai rataan yang lebih tinggi dibandingkan kultur dalam media tanpa ZPT (kontrol), sementara nilai rataan panjang planlet dan keberhasilan hidup kultur lebih tinggi pada kultur dalam media tanpa ZPT (Tabel 1). Pengaruh ZPT terhadap inisiasi tunas juga terjadi pada kultur klon lili. Keberadaan ZPT tersebut berpengaruh terhadap inisiasi tunas paling cepat, terjadi pada kultur klon lili dalam media MS yang mengandung $2 \mathrm{mg} / \mathrm{l}$ $\mathrm{BA}+1 \mathrm{mg} / \mathrm{l} \mathrm{NAA}$, yaitu pada hari ke-13 setelah tanam. Media yang paling banyak menghasilkan tunas adalah MS + BA $1 \mathrm{mg} / \mathrm{l}$ + NAA 2 mg/l (http://suhudoedin.blogspot. com/2008/08/kultur-jaringan-lyly.html ${ }^{15}$.

Tabel 1. Pengaruh perlakuan BA terhadap pembentukan tunas dan parameter pertumbuhan lainnya pada kultur Eleutherine sp. 6 minggu setelah inisiasi

\begin{tabular}{|l|l|l|l|c|}
\hline \multicolumn{1}{|c|}{ Perlakuan } & $\begin{array}{c}\text { Rataan jumlah } \\
\text { tunas }\end{array}$ & Rataan jumlah daun & $\begin{array}{c}\text { Rataan panjang } \\
\text { tunas }(\mathrm{cm})\end{array}$ & $\%$ Hidup \\
\hline Kontrol & $2,00 \pm 0,71$ & $2,40 \pm 1,14$ & $7,36 \pm 1,56$ & 100 \\
\hline BA 1 mg/l & $6,20 \pm 1,10$ & $6,40 \pm 2,88$ & $6,10 \pm 0,70$ & 97 \\
\hline
\end{tabular}

Keterangan: angka yang tercantum dalam tabel di atas merupakan nilai rataan \pm standar deviasi 
ZPT yang ditambahkan ke dalam media kultur jaringan untuk mengatur pertumbuhan dan perkembangan eksplan. Rasio antara ZPT dari luar dengan hormon yang diproduksi tanaman (endogen) akan menentukan arah perkembangan kultur dan tipe pembentukan organnya. Penambahan ZPT dari luar tersebut akan mengubah level ZPT endogen, dengan demikian level baru ZPT akan menjadi faktor pemicu untuk proses pertumbuhan dan morfogenesis eksplan (Gunawan, 1988) ${ }^{16}$. Respon positif terhadap perlakuan ZPT dari luar tampak pada kultur eksplan umbi amarilis dalam media yang mengandung sitokinin. Eksplan berhasil meningkatkan jumlah tunas secara in vitro pada media yang mengandung $1 \mathrm{mg} / \mathrm{l}$ BA (Hoesen, 2003a) $)^{17)}$. kemudian nilai rataan tersebut menurun secara nyata pada medium yang ditambah $5 \mathrm{mg} / \mathrm{l} \mathrm{BA}$. Dari kejadian tersebut tampak ada konsentrasi ZPT yang meningkatkan (1 mg/l BA), mencapai optimal (2 mg/l BA) dan menurunkan pembentukan tunas ( $5 \mathrm{mg} / \mathrm{l}$ BA) (Gambar 1 dan Tabel 2). Kejadian yang hampir sama terjadi juga pada kultur Crinum $\mathrm{sp}$. (Liliaceae), penambahan $2 \mathrm{mg} / \mathrm{B}$ BA menghasilkan jumlah rataan tunas tertinggi. (Hoesen, 2003b) ${ }^{18)}$. Kultur Lilium sp. (Fam. Liliaceae; Ordo Liliales) yang termasuk satu ordo dengan Eleutherine sp. berhasil membentuk tunas, akar dan daun dengan nilai rataan tertinggi dalam media MS yang ditambah 2 mg/l BA (Hoesen, 2009) ${ }^{19}$.

Nilai rataan jumlah daun tertinggi dihasilkan oleh kultur dalam media yang

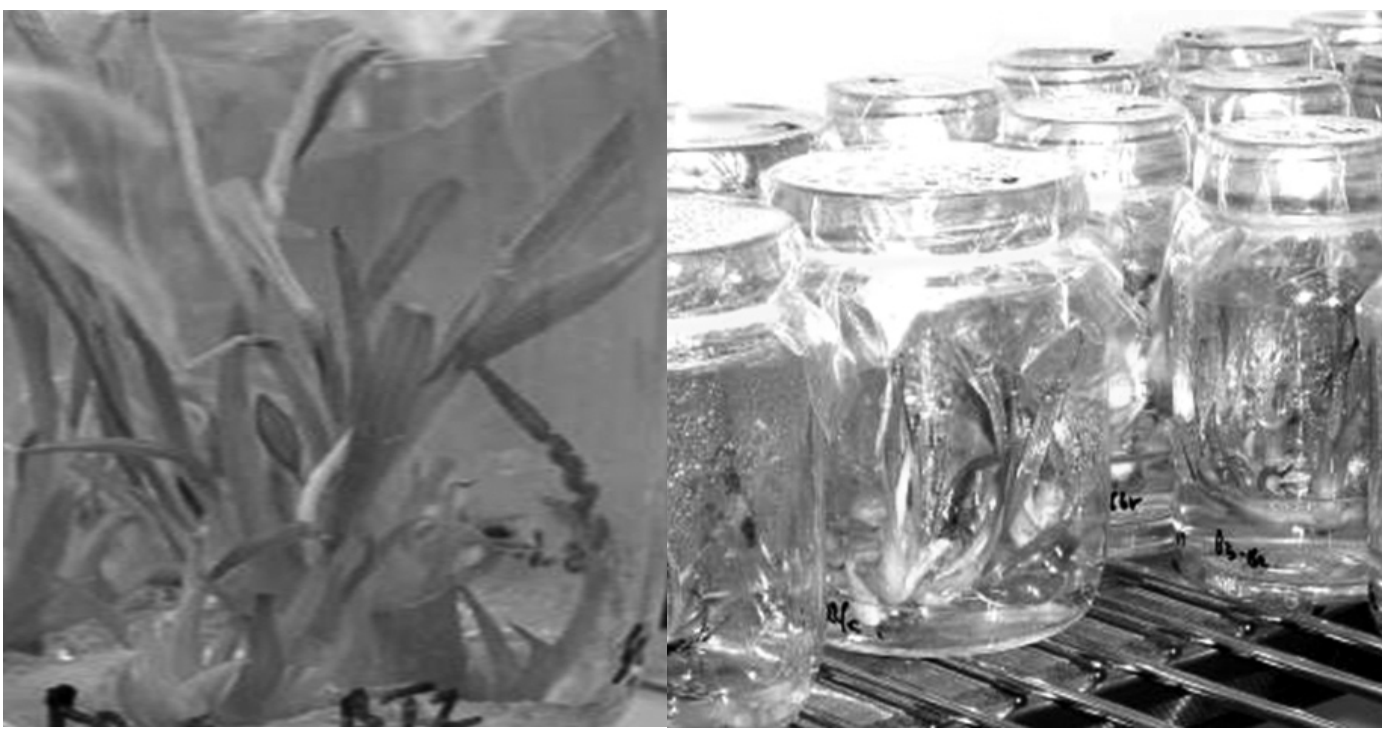

Gambar 3. Kultur dalam media untuk induksi pembentukan tunas

Pada tahap perbanyakan, kultur dalam media yang mengandung $2 \mathrm{mg} / \mathrm{l}$ BA menghasilkan nilai rataan jumlah tunas tertinggi dibandingkan dengan kultur dalam medium $1 \mathrm{mg} / \mathrm{l} \mathrm{BA}$ dan tanpa ZPT. Perlakuan penambahan (0, 1 dan 2 ) $\mathrm{mg} / \mathrm{l}$ BA menunjukkan pengaruh yang nyata terhadap pembentukan tunas, semakin tinggi konsentrasi BA semakin tinggi pula nilai rataan pembentukan tunasnya, tetapi ditambah $1 \mathrm{mg} / \mathrm{BA}$, nilai rataan kultur dalam media yang ditambah (1,2 dan 5) mg/l BA tersebut berbeda nyata dibandingkan dengan kontrol (tanpa ZPT) (Gambar 2 dan Tabel 2).

Keadaan yang agak berbeda tampak pada nilai rataan panjang tunas/planlet, kultur tanpa ZPT menghasilkan panjang/ tinggi planlet relatif lebih tinggi dibandingkan dengan planlet dalam media yang ditambah (1 dan 5) mg/l BA (Gambar 3 dan Tabel 2). 
Tabel 2. Pengaruh perlakuan BA terhadap pertumbuhan planlet kultur Eleutherine sp. 8 minggu sejak subkultur1

\begin{tabular}{|c|c|c|c|}
\hline Perlakuan (mg/l) & Rataan jumlah tunas & Rataan jumlah daun & Rataan panjang tunas $(\mathrm{cm})$ \\
\hline BA 0 (Kontrol) & $2,40^{a}$ & $2,60^{a}$ & 7,36 ab \\
\hline BA 1 & $6,80^{b}$ & $7,60^{c}$ & $6,34^{a}$ \\
\hline BA 2 & $11,40^{c}$ & $5,80^{\mathrm{b}}$ & $8,26^{b}$ \\
\hline BA 5 & $6,40^{b}$ & $6,2^{\mathrm{b}}$ & $6,66^{a}$ \\
\hline
\end{tabular}

Keterangan: Angka yang bertanda huruf sama dalam satu kolom menunjukkan hasil yang tidak beda nyata dalam uji beda rata-rata, nilai $p \leq 0,05$

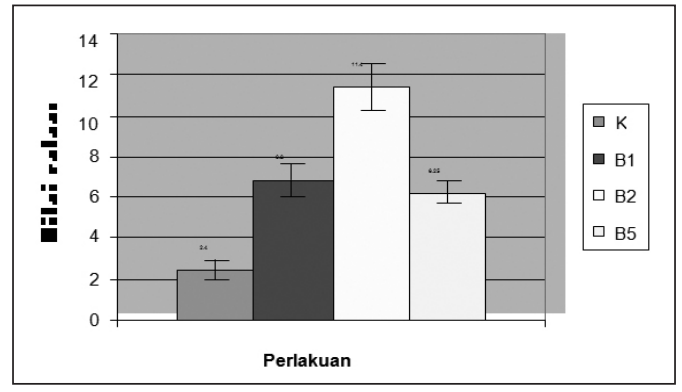

Gambar 1. Pengaruh perlakuan terhadap pembentukan tunas Eleutherine sp.8 minggu sejak subkultur 1

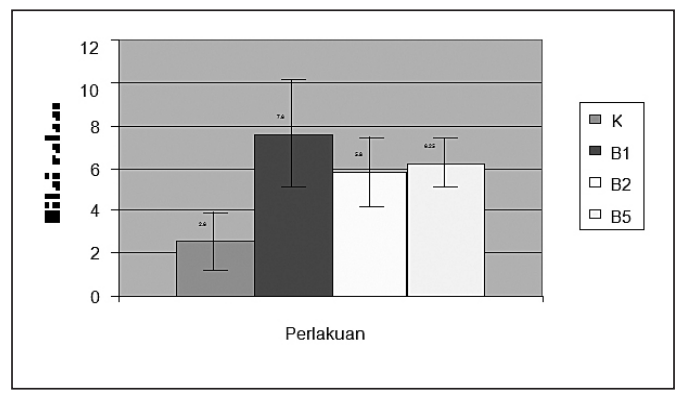

Gambar 2. Pengaruh perlakuan terhadap pembentukan daun planlet Eleutherine sp. 8 minggu sejak subkultur

Nilai rataan tunas dan jumlah daun tertinggi pada 8 minggu setelah subkultur ke

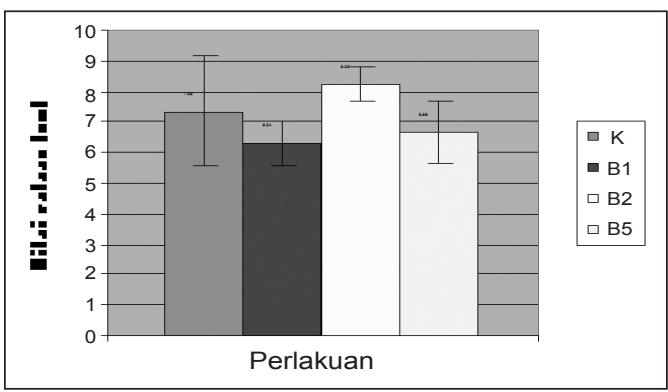

Gambar 3. Pengaruh perlakuan terhadap pertumbuhan panjang tunas/ planlet Eleutherine sp. 8 minggu sejak subkultur1

dua, menunjukkan bahwa perlakuan $2 \mathrm{mg} / \mathrm{l}$ BA pembentukan tunas $(9,33)$ dan daunnya $(9,00)$ nilai tersebut tertinggi dibandingkan dengan perlakuan lainnya, namun cenderung menurun dibandingkan dengan nilai rataan pada subkultur pertama $(11,40)$, sementara tanpa ZPT atau kontrol (2,00). Penambahan auksin $(0,5 \mathrm{mg} / \mathrm{N} \mathrm{NAA})$ tanpa sitokinin membentuk kalus (Foto 3 ) dan perlakuan 2 $\mathrm{mg} / \mathrm{BA}$ yang dikombinasikan dengan 0,5 mg/l NAA berhasil membentuk tunas berakar. Tunas terpanjang dihasilkan oleh kultur dalam media tanpa ZPT $(6,77 \mathrm{~cm})$ (Tabel 3, Gambar 4, 5 dan 6 )

Tabel 3. Pengaruh perlakuan terhadap pertumbuhan tunas kultur bawang sabrang 8 minggu setelah subkultur 2

\begin{tabular}{|l|l|l|l|l|}
\hline $\begin{array}{c}\text { Perlakuan } \\
(\mathrm{mg} / \mathrm{l})\end{array}$ & \multicolumn{1}{|c|}{$\begin{array}{c}\text { Rataan jumlah } \\
\text { tunas }\end{array}$} & \multicolumn{1}{|c|}{$\begin{array}{c}\text { Rataan jumlah } \\
\text { daun }\end{array}$} & $\begin{array}{c}\text { Rataan jumlah } \\
\text { akar }\end{array}$ & $\begin{array}{c}\text { Rataan panjang } \\
\text { tunas }\end{array}$ \\
\hline $\mathrm{B} 0(\mathrm{~K})$ & $2,00 \pm 1,73$ & $2,00 \pm 0,00$ & $4,33 \pm 2,08$ & $\mathbf{6 , 7 7} \pm \mathbf{0 , 5 9}$ \\
\hline $\mathrm{B} 2$ & $\mathbf{9 , 3 3} \pm \mathbf{1 , 5 3}$ & $\mathbf{9 , 0 0} \pm \mathbf{2 , 0 0}$ & $0,00 \pm 0,00$ & $5,73 \pm 0,51$ \\
\hline $\mathrm{B} 2 \mathrm{~N} 0,5$ & $2,33 \pm 1,53$ & $3,33 \pm 1,15$ & $\mathbf{7 , 6 7} \pm \mathbf{3 , 5 1}$ & $3,90 \pm 0,53$ \\
\hline $\mathrm{N} 0,5$ & Kalus & Kalus & Kalus & Kalus \\
\hline
\end{tabular}

Keterangan: * Terjadi pembentukan kalus

Angka yang tercantum dalam tabel di atas merupakan nilai rataan \pm standar deviasi 


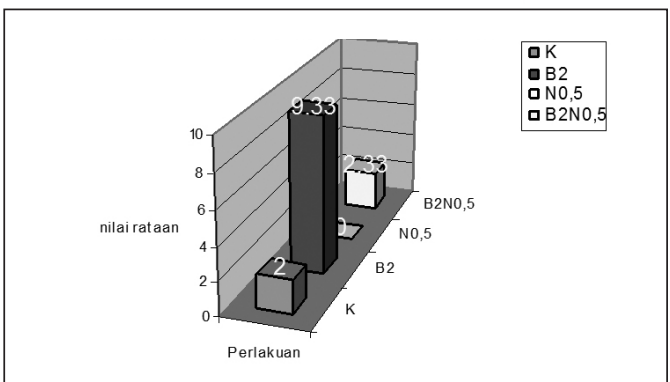

Gambar 4.Pengaruh perlakuan auksin dan sitokinin terhadap pembentukan tunas kultur Eleutherine sp. 8 minggu sejak subkultur2

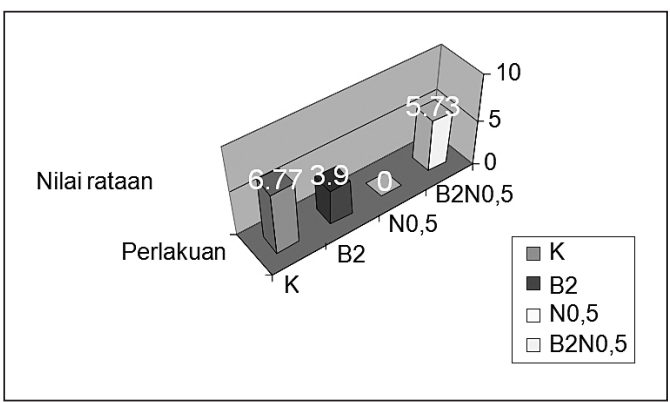

Gambar 5. Pengaruh perlakuan terhadap pertumbuhan planet Eleutherine sp. 8 minggu sejak subkultur2

Respon ZPT terhadap pertumbuhan dan multiplikasi tunas kultur bawang sabrang, keadaannya hampir sama dengan kultur Lilium Iongiflorum (Ordo Liliales), pada penelitian tersebut teramati bahwa NAA dan BAP berpengaruh positif terhadap multiplikasi tunas aksiler. (Armelia. 2004 http://digilib.bi.itb.ac.id/go.php?id=jbptitbbigdl-s1-1994-mariaarmel-800) ${ }^{11)}$. Laporan penelitian teknik in vitro pada Eleutherine belum diperoleh, karena itu kami mengacu kepada hasil kultur jaringan jenis yang relatif dekat kerabatnya (Ordo) dan jenis lainnya.

\section{1) Induksi kalus}

Kalus yang terbentuk dalam media yang mengandung 0,5 mg/l NAA (Gambar 3 ), diinduksi untuk membentuk kalus yang embriogenik dengan perlakuan (0,5 dan 1) $\mathrm{mg} / \mathrm{l}$ 2,4-D dan $1 \mathrm{mg} / \mathrm{l}$ pikloram secara tunggal atau dikombinasikan. Pada kultur dalam media yang mendapat perlakuan

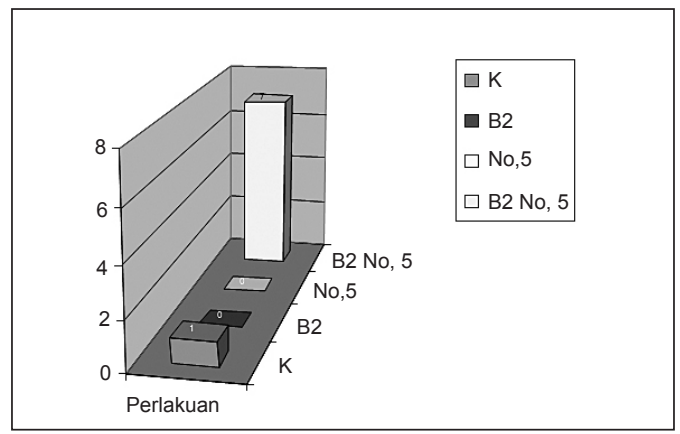

Gambar 6. Pengaruh perlakuan terhadap pembentukan akar planlet Eleutherine sp. 8 minggu setelah subkultur 2

2,4-D, ada kecenderungan meningkatnya konsentrasi seiring dengan meningkatnya ukuran diameter kalus yang dihasilkan (Tabel 4). Keadaan yang hampir serupa juga terjadi pada perlakuan pikloram secara tunggal dengan perlakuan kombinasi antara (0,5 dan 1) mg/l 2,4-D dan $1 \mathrm{mg} / \mathrm{l}$ pikloram yang berhasil membentuk kalus yang diduga embriogenik dengan struktur remah dan berwarna kekuningan (Gambar 4). Diameter kalus tertinggi dihasilkan oleh kultur dalam media yang ditambah kombinasi antara 1 mg/l 2,4-D dan $1 \mathrm{mg} / \mathrm{l}$ pikloram (Tabel 4).

Induksi kalus tersebut berhasil pula pada kultur tanaman lainnya, seperti Safflower L. cv. Bhima. Penambahan auksin (2,4D; NAA, IAA) secara tunggal dan dikombinasikan dengan sitokinin (BA, kinetin), diaplikasikan pada kultur berbagai macam eksplan (akar, hipokotil, kotiledon dan potongan daun), berhasil membentuk kalus. Keadaan tersebut terjadi pula pada kultur PLB D. lineale, penambahan 2,4-D secara tunggal hingga $5 \mathrm{mg} / \mathrm{l}$ berhasil membentuk kalus 95,45 \% (Hoesen, et al. 2008) ${ }^{19)}$. ZPT auksin 2,4-D sering digunakan untuk merangsang inisiasi kalus, dalam proses inisiasi embriogenesis somatik terutama 2,4-D dengan konsentrasi tinggi (George, 1993) ${ }^{20)}$

\section{2) Pembesaran Planlet}

Subkultur ke tiga, planlet dari media yang mengandung $5 \mathrm{mg} / \mathrm{l} \mathrm{BA}$ dipindahkan ke media MS yang mengandung $2 \mathrm{mg} / \mathrm{l} \mathrm{BA}$ 
dan media MS tanpa ZPT. Rataan jumlah tunas 7,4 ; jumlah daun 5,2 dan tinggi planlet mencapai rataan $5,08 \mathrm{~cm}$, tanpa akar (Tabel 5). Untuk pembesaran, planlet dipindahkan

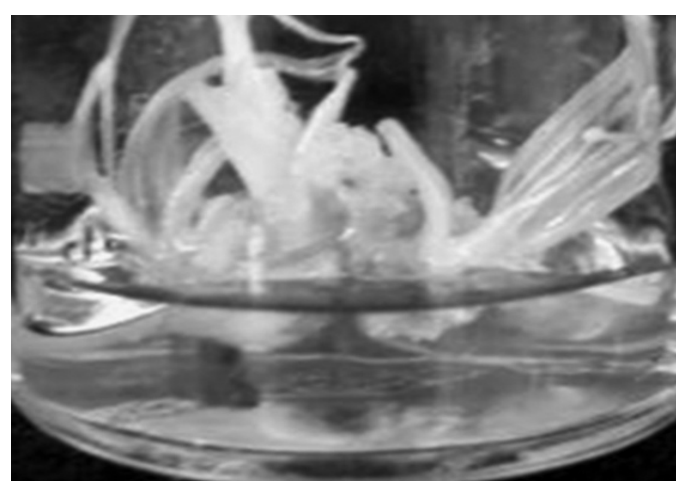

\section{3) Aklimatisasi}

Tanaman lengkap dengan morfologi yang proporsional (tinggi sekitar $15 \mathrm{~cm}$, akar lebih dari 5), siap untuk dipelihara secara ex vitro dalam media tanah yang dicampur

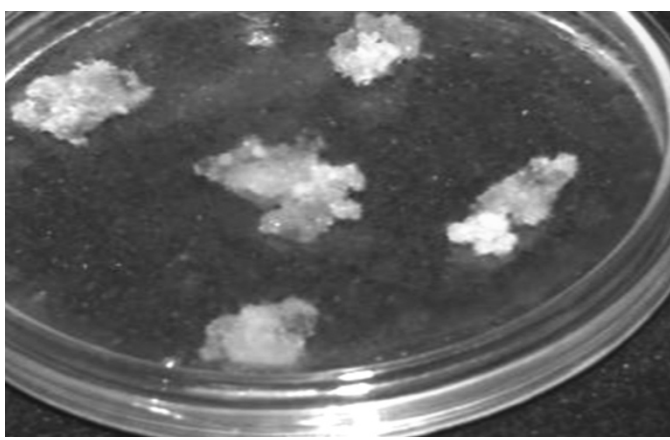

Gambar 4 dan 5. Pembentukan kalus Eleutherine sp. pada media 0,5 mg/l NAA dan Induksi pembentukan kalus embrionik Eleutherine sp.

Tabel 4. Pengaruh perlakuan Pikloram dan 2,4-D terhadap pembentukan kalus Eleutherine sp.

\begin{tabular}{|l|l|l|l|}
\hline \multicolumn{2}{|c|}{ Perlakuan (mg/l) } & Diameter kalus (mm) & Kultur membentuk kalus (\%) \\
\hline Pikloram & \multicolumn{1}{|c|}{$\mathbf{2 , 4 - D}$} & & \\
\hline 0 & 0 & $7,00 \pm 0,71$ & 100 \\
\hline 0 & 0,5 & $8,40 \pm 1,14$ & 100 \\
\hline 0 & 1 & $9,00 \pm 1,00$ & 100 \\
\hline 1 & 0 & $8,20 \pm 1,10$ & 100 \\
\hline 1 & 0,5 & $8,80 \pm 1,64$ & 100 \\
\hline 1 & 1 & $9,20 \pm 1,30$ & 100 \\
\hline
\end{tabular}

Keterangan: Angka yang tercantum dalam tabel di atas merupakan nilai rataan \pm standar deviasi

Tabel 5. Nilai rataan parameter pertumbuhan pada subkultur ke 3 dan tahap pembesaran kultur Eleutherine sp.

\begin{tabular}{|l|l|l|l|l|}
\hline \multirow{2}{*}{\multicolumn{1}{|c|}{ Parameter }} & \multicolumn{2}{c|}{ Nilai rataan } & \multicolumn{2}{c|}{ \% hidup } \\
\cline { 2 - 5 } & \multicolumn{1}{|c|}{ Subkultur 3 } & \multicolumn{1}{c|}{ Pembesaran } & \multicolumn{1}{c|}{ Subkultur 3 } & Pembesaran \\
\hline Jumlah tunas & $7,4 \pm 2,07$ & $2,6 \pm 1,34$ & 100 & 100 \\
\hline Jumlah daun & $5,2 \pm 2,77$ & $2,2 \pm 1,30$ & 100 & 100 \\
\hline Jumlah akar & 0 & $4,2 \pm 1,10$ & 100 & 100 \\
\hline Panjang tunas $(\mathrm{cm})$ & $5,1 \pm 0,92$ & $10,4 \pm 0,78$. & 100 & 100 \\
\hline
\end{tabular}

Keterangan: Angka yang tercantum dalam tabel di atas merupakan nilai rataan \pm standar deviasi

ke media tanpa ZPT dengan nilai rataan tunas $2,6 \pm 1,34$; jumlah daun $2,2 \pm 1,30$, jumlah akar 4,2 $\pm 1,10$ dan tinggi tunas/ planlet 10,44 \pm 0,78 (Tabel 5, Gambar 5). dengan kompos dan pasir steril. Seluruh planlet/tanaman dapat bertahan hidup dan tumbuh baik hingga 4 minggu di rumah kaca. Menghasilkan umbi setelah dipindahkan ke media tanah/lapangan (Gambar 6). 


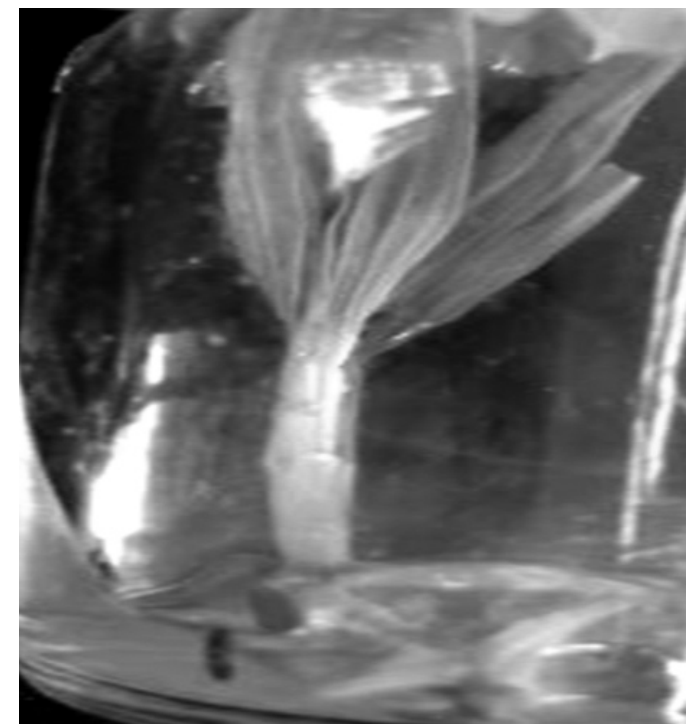

Gambar 5. Planlet/tanaman lengkap yang siap diaklimatisasi

\section{KESIMPULAN}

Pembudidayaan in vitro Eleutherine sp. dapat diaplikasikan untuk menghasilkan tanaman secara massal, sebagai upaya menyediakan bahan baku obat terutama untuk pengobatan kanker yang tidak boleh terhenti pengobatannya (terus menerus). Dengan dihasilkannya kalus yang embriogenik, maka peluang untuk meningkatkan kualitas genetik dari tumbuhan tersebut akan terbuka, terutama apabila akan menyeleksi kandungan senyawa aktifnya. Diharapkan dengan teknik ini dapat menyokong industri obat. Percobaan kultur kalus tersebut perlu dilanjutkan untuk meningkatkan kualitas genetiknya atau untuk mendapatkan varitas yang lebih unggul. Tidak kalah pentingnya adalah untuk meningkatkan potensi Eleutherine sp. sebagai tanaman hias di pekarangan selain untuk Toga (Tanaman Obat Keluarga) dan di taman kota.

\section{UCAPAN TERIMA KASIH}

Terimakasih saya sampaikan kepada Engkom Komarudin Teknisi Litkayasa yang telah membawakan bahan penelitian dari
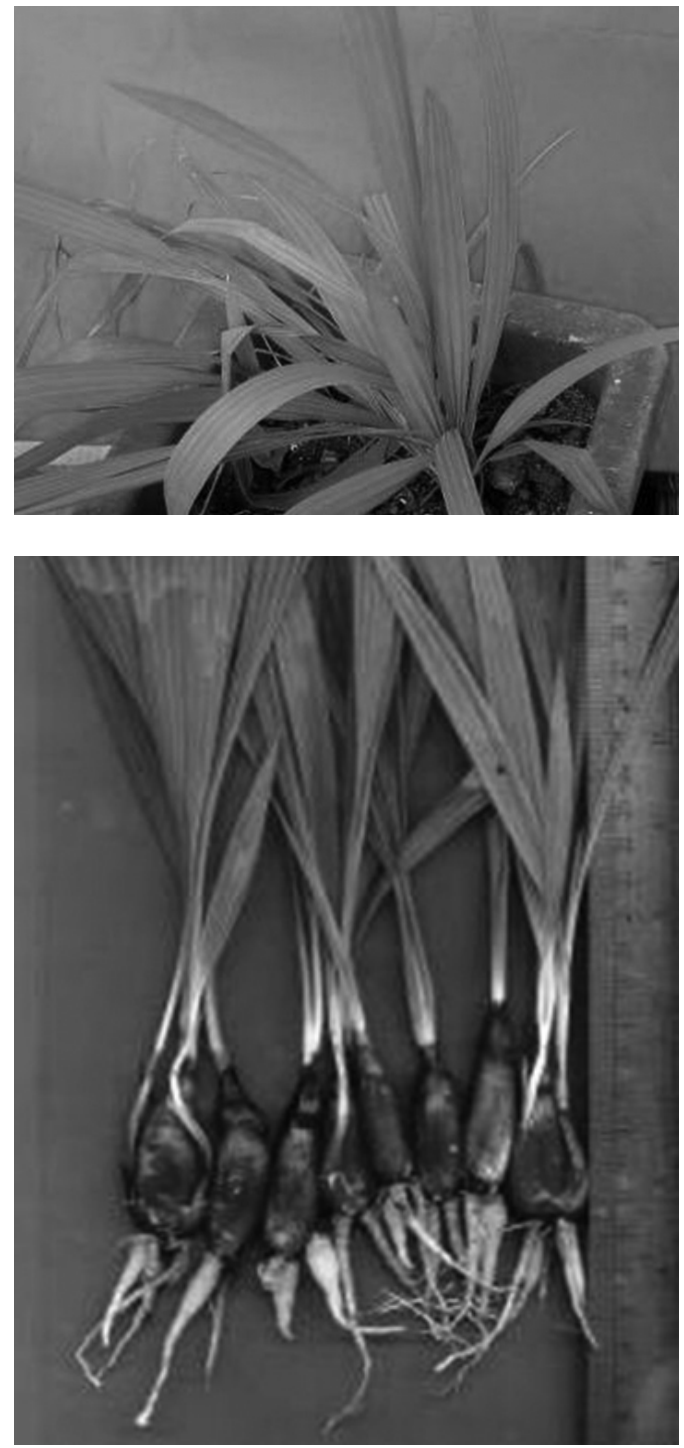

Gambar 6. Tanaman setelah aklimatisasi

habitat alaminya di Desa Teun, Kab. Belu Nusa Tenggara Timur dan Niar SHut. yang telah membantu pekerjaan di laboratorium Kultur Jaringan Bidang Botani, Puslit BiologiLIPI. CSC

\section{DAFTAR PUSTAKA}

1. Heyne, K. 1987. Iridaceae. Tumbuhan Berguna Indonesia. Jilid I, 551-552. Badan Litbang Kehutanan. Jakarta. 616 halaman. 
2. Backer, A and RC. Bakhuizen van den Brink, 1968. Flora of Java Vol. III. Wolters Noordhoff NV-Groningen-The Netherlands. 761 pages.

3. Anonim, 2009b. Bawang Dayak (Eleutherine americana Merr.) http://www. bazar.co.id; http://www.kalteng.litbang. deptan.go.id. Generated 19 Maret 2009

4. Bintari, NR., 2002. Bawang dayak lenyapkan kanker payudara. Trubus 396 - November 2002/XXXIII, 55-56.

5. Winarto, WP., 2007. Tanaman Obat Indonesia untuk Pengobat Herbal. Jilid 3, 55-57. Karya Sari Herba Media. Jakarta.

6. Perry, LM and J. Metzger, 1980. Medicinal plants of East and South East Asia Attributed Properties and Uses. The MIT Press Cambridge, Massachusetts and London England.

7. Anonim, 2007. Hasil Diskusi dan Kesepakatan KoordinasiKelompokKerja Penanggulangan Penyakit Layu Pisang, yang diselenggarakan di Banjarmasin pada tanggal 18 - 20 April 2007. http:// insidewinme.blogspot.com/2007/11/ penanggulangan-penyakit-layu-pisang. html

8. Sa'roni., Nurendah. P dan Adjirni, 1987. Penelitian Efek Anti inflamasi Beberapa Tanaman Obat pada Tikus Putih (Rat) (Publikasi terbatas) Dibacakan pada Kongres Biologi Nasional VIII, 8 - 10 Oktober 1987 di Purwokerto.

9. Firdaus, R; Sukrasno dan S. Kusmardiyani, 2007. Telaah Kandungan Kimia Ekstrak Metanol Umbi Bawang Tiwai (Eleutherine americana (Aubl.) Merr.) http://bahan-alam.fa.itb.ac.id/ detail Generated 19 Maret 2009
10. Hara, H; N. Maruyana; S. Yamashita; Y. Hayashi; KH. Lee; KF. Bastow, RM. Chairul and Y. Imakura. 1997. Elecanacin, a novel new naphthaquinone from the bulb of Eleutherine americana. Chem. Pharm. Bull. 45. 1714-1716

11. Alves, TMA; H. Kloos and CL. Zani, 2003. Eleutherinone, a novel fungitoxic naphthoquinone from Eleutherine bulbosa (Iridaceae). Mem. Inst Ostwaldo Cruz, Rio de Janeiro 98(5), 709-712. http:// memorias.ioc. fiocruz.br/985/4784.pdf. Generated 28 Februari 2008

12. Jinzhong, X; Q. Feng; D. Wenjuan; Q. Gexia. W. Naili and Y. Xinsheng. 2006. New bioactive constituents from Eleutherine americana. Front. Chem. China Vol. 3, 320-323 http://www. springerlink.com/content/fulltext.pdf. Generated 04 Maret 2009

13. Han, A; J. Lee; H. Min, A. Wiryawan; SK. Lee and E. Seo. 2006. http:// wwwphcog.org/Annual/Mtg/2006/ papers/pdf. Generated 28 Februari 2008

14. Ming LC. 1995. Yield of Eleutherine bulbosa - Iridaceae as affected by weight of bulbs and planting spacing. Presented in International Symposium on Medicinal and Aromatic Plants. www.actahort. org. Generated 19 Maret 2009

15. http://suhudoedin.blogspot. com/2008/08/kultur-jaringan-lyly.html. Generated 20 Februari 2009

16. Gunawan, LW. 1988. Teknik Kultur Jaringan. Pusat Antar Universitas. Bioteknologi IPB. Bogor.

17. Hoesen, DSH, 2003a. Perbanyakan Amaryllis sp. (AMARYLLIDACEAE) secara in vitro. Gakuryoku Vol. IX(2), 159-163. 
18. Hoesen, DSH, 2003b. Pertumbuhan dan perkembangan Crinum sp. secara in vitro. Gakuryoku Vol. IX(1), 54-58

19. Hoesen, DSH., Witjaksono dan LA. Sukamto, 2008. Induksi kalus dan organogenesis kultur in vitro Dendrobium lineale Rolfe. Berita Biologi 9(3), 333-341
20. George, EF. 1993. Plant Propagation by Tissue Culture in Practice Part 1. Exegetic Limited England. ISBN 0-9509325-4-X. 